https://doi.org/10.15407/frg2019.06.482

UDC 633.15:577.34:58.087

\title{
THE DETAILED STUDY OF LEAF INFRARED SPECTRUM PARAMETERS - A CONTRIBUTION TO THE OVERALL CHARACTERISATION OF MAIZE INBRED LINES PROPERTIES
}

\author{
Č.N. RADENOVIĆ ${ }^{1,2}$, G.V. MAKSIMOV ${ }^{3}$, V.V. SHOUTOVA ${ }^{4}$, O.V. SLATINSKAYA ${ }^{3}$, \\ F.F. PROTOPOPOV ${ }^{3}$, N.S. DELIĆ ${ }^{1}$, M.V. MILENKOVIĆ ${ }^{1}$, Z.F. ČAMDŽIJA ${ }^{1}$, \\ N.M. GRCIC ${ }^{1}$, J.M. PAVLOV ${ }^{1}$
}

${ }^{1}$ Maize Research Institute, Zemun Polje, Slobodana Bajića 1, 11185 Belgrade, Serbia ${ }^{2}$ University of Belgrade, Faculty for Physical Chemistry, Studenski trg 12-16, 11000 Belgrade, Serbia

${ }^{3}$ M.V. Lomonosov Moscow State University, Faculty of Biology, Leninskie Gory, 12, 119892 Moscow, Russia

${ }^{4}$ Ogarev Mordovia State University, Bolshevitskaya St., 68, 430005 Saransk, Republic of Mordovia, Russia

e-mail: radenovic@sbb.rs

Results and discussion about observation of leaf infrared spectrum parameters with the intention of overall characterisation of the traits of the elite maize inbred lines ZPPL 186, ZPPL 225, ZP M1-3-3 Sdms are presented. The proposed hypothesis was that numerous spectral bands of maize inbred lines leaves, not observed yet, but occurring in the different kinetic forms (bands of high and low intensity, single or grouped), should be systematically studied and the dynamics of their formation, very often caused by different oscillations and vibrations of molecular bonds, should be explained. In some cases, there is a possibility of the partial cancellation or increase of spectral bands intensity. According to our hypothesis, low intensity spectral bands imply the unstable state of the biological system (leaf), which is a consequence of the excited state of molecules, radicals, atoms or ions in tissues, cells or biomembranes. Similar transport processes occur when biological systems are rhythmically excited, as well as when complex transport of ions occur across the excited thylakoid membrane. These bands most frequently appear in the wave number range of $500-1600 \mathrm{~cm}^{-1}$. Nevertheless, they fractionally occur in the wave number up to $3000 \mathrm{~cm}^{-1}$. These spectral bands varied over inbred lines used in this study. The systematic analysis of spectral bands of leaves of observed maize inbred lines (for instance, high intensity bands with significant width on $3370 \mathrm{~cm}^{-1}$ ) showed the difference in their occurrence: the most intensive occurrence was in leaves of the inbred line ZPPL 186, then in ZP M1-3-3 Sdms, while the lowest intensity was detected in the inbred line ZPPL 225. In such a complex way, it is possible to identify not only organic compounds and their structure in leaves of observed maize inbred lines, but also to indicate the possibility of complex inducement of their unstable and conformational states.

Key words: Zea mays L., inbred line, leaf, infrared spectra, spectral bands.

Nowadays, the fundamental progress in the diagnosis of the state of organs and vital functions of the whole plant at the molecular level is accom-

\footnotetext{
(c) Č.N. RADENOVIĆ, G.V. MAKSIMOV, V.V. SHOUTOVA, O.V. SLATINSKAYA, F.F. PROTOPOPOV, N.S. DELIĆ, M.V. MILENKOVIĆ, Z.F. ČAMDŽIJA, N.M. GRCIC, J.M. PAVLOV, 2019 482
} 
plished with contemporary methods of spectroscopy. The vibrational spectroscopy (infrared and Raman) is a challenging method in the analysis of infrared spectra of organic molecules resulting from molecular vibrations, thus it is possible to obtain many other results about the structure, dynamics and the nature of observed plant systems [1-5].

The Raman spectroscopy was applied in our previous studies [6-9] to analyse structural changes of carotenoid molecules in kernels of various maize inbred lines and hybrids. These analyses showed that the structure of these molecules could be used as a molecular marker in the assessment of agronomic traits of the maize inbred lines and hybrids. Our lately published papers [10-12] present the application of infrared spectroscopy method in studying the formation of infrared spectra. The special attention was paid to four or five most pronounced spectral bands [10-12]. However, numerous low intensity spectral bands were not analysed in these studies. It was done in the recent study [13].

The infrared spectroscopy was used in our study to analyse not only high intensity, but also low intensity and insufficiently differentiated spectral bands. The goal was to identify the unstable state of the excited plant system and life functions of leaves of studied maize inbred lines. It was revealed that bioactive organic compounds and their structure could be identified with the infrared spectroscopy. Furthermore, information on oscillatory behaviour of molecular bonds of organic compounds and their functional groups in leaves of observed maize inbred lines was obtained [12-13].

The objective of this study was to develop a methodology for analyses of numerous high and low intensity spectral bands of various shapes and kinetics, with the purpose of identifying organic compounds and their functional groups, and indicating traits of observed maize inbred lines.

\section{Materials and methods}

Leaves of three high yielding maize inbred lines ZPPL 186, ZPPL 225 and ZP M1-3-3 Sdms were used in this study. These inbred lines had been developed at the Maize Research Institute, Zemun Polje, Belgrade, Serbia. Numerous morphological and agronomic properties of studied maize inbred lines, including their relevant breeding and seed production traits, as well as their characteristics of a photosynthesis model have been comprehensively presented in our previously published manuscript [10].

The technique of infrared spectroscopy applied in the analysis of leaves of maize inbred lines involves spectrophotometers used in the infrared spectrum region. With regard to the sequence of components, these spectrophotometers are not different from those used in the ultraviolet and visible spectrum. Specificities, nevertheless, occur in the very principle of the work of the spectrophotometer. The basic dissimilarities relate to the source of radiation, type of samples, the principle of absorption of radiation, as well as, the use of diverse detectors (thermal and photo-detectors) $[1,5]$.

At the present time, interferometers, special types of spectrophotometers, are predominantly used. These types of spectrophotometers, based on the principles of interferometry, do not produce the spectrum itself, but an 
interferogram, which is then processed by a computer into a common spectral shape. This is co-called the Fourier transformation, and thus the name the Fourier transform spectroscopy (FTS). These instruments are particularly suitable for the use in the far-infrared region and are characterised by a good resolution [10-13].

In order to register infrared spectra of the observed maize inbred lines, leaves were homogenised and pressed into the tablet form with the addition of potassium bromide $(\mathrm{KBr})$. The spectrum was recorded within the spectral range of $500-3500 \mathrm{~cm}^{-1}$ with the Furier transform infrared spectrometer Shimadzu IR-Prestige 21 (Shimadzu Corporation). This method has been described in details in our previous manuscript [15], including the modus operandi and the optical scheme of the device for infrared spectra registering.

Several leaves of observed maize inbred lines were randomly sampled. Samples were prepared in the following way: leaves were ground and homogenised in an agate mortar and then mixed with potassium bromide $(\mathrm{KBr})$ and rolled into samples - tablets with the component ratio of 1:100.

The primary processing of infrared spectra was done by the OriginPro software package 2017 (OriginLab Corporation, USA).

The calculations were made by Microsoft Excel 2013 software package (Microsoft Corporation, USA).

The statistical calculations were mainly done by using the program package Statistica, version 10 (StatSoft, Inc, USA).

\section{Results and discussion}

Generally, analysed infrared spectra for three maize inbred lines were characterised by numerous spectral bands (Fig. 1, $a, b, c$ ). The number of bands was up to 30 within the range of the wave number from 500 to $3500 \mathrm{~cm}^{-1}$. According to their kinetic parameters, they differed considerably from one another. There were at least three classes. Similar spectral bands were formed within the range of the wave number of $1250-500 \mathrm{~cm}^{-1}$. Somewhat different spectral bands were formed within the range of the wave number of $1535-1400 \mathrm{~cm}^{-1}$. Finally, there were spectral bands that were formed within the ranges of the wave numbers of $2250-1795 \mathrm{~cm}^{-1}$ and $2725-2410 \mathrm{~cm}^{-1}$. The registered spectral bands were of high and low intensity, clearly separated or grouped and some of them had a complex structure. There are no data in literature about such spectral bands of leaves of maize inbred lines, since they had not been studied and analysed yet. Our study was actually focused on all spectral bands of low and high intensities and with specific kinetic parameters.

According to our hypothesis, the low intensity spectral bands with different kinetic parameters suggest an unstable (excited) state of the biological system (leaf) [13-15]. Furthermore, the excited state is expressed in certain functional groups of organic compounds. It should not be forgotten that the unstable states of the biological system (tissue, cells, membranes) are a consequence of the excited state of molecules, radicals, atoms or ions, and that they are inevitably accompanied by changes in kinetic energy and thus by different movement modes of molecular bonds (oscillations, vibrations, rotations, translations), which, by superposition of ener- 

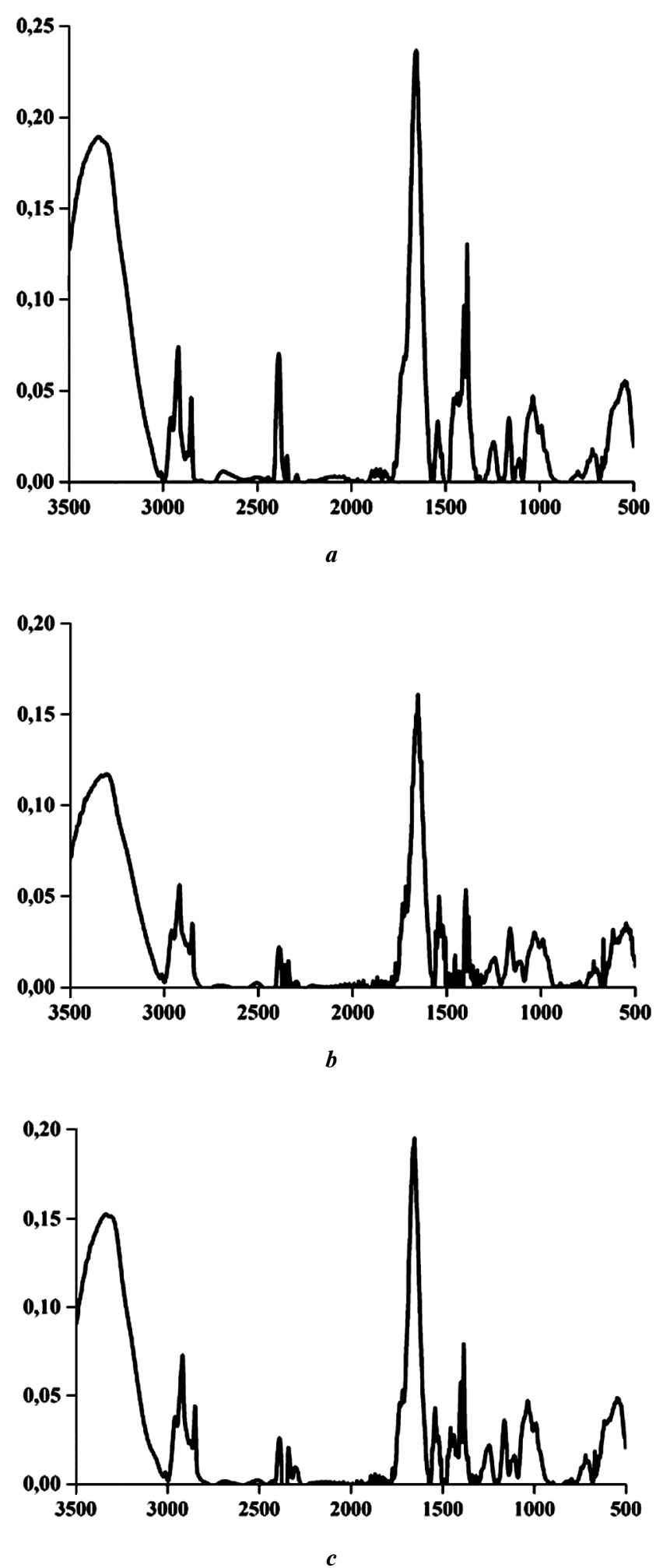

Fig. 1. Infrared spectra of leaves of maize inbred lines:

$a$ - ZPPL 186; $b$ - ZPPL 225; $c$ - ZP M1-3-3 Sdms. Abscissa - wave number, $\mathrm{cm}^{-1}$, ordinate intensity of absorption of infrared radiation, relative units 
gies, can lead to partial cancellation or increase of the intensity of the movement process of molecular bonds. Such a mode of the movement develops the different intensities of spectral bands.

Fig. 2 is an illustration of the hypothesis that superposition of neighbouring low intensity spectral bands can partially cancel or increase intensity of the spectral band. It shows one spectral band of the infrared spectrum of leaves of maize inbred lines. The absorption intensity of infrared radiation was measured towards wave numbers from $1250 \mathrm{~cm}^{-1}$ to $1500 \mathrm{~cm}^{-1}$. The molecular bonds of the organic compounds with the characteristic spectral band at $1305 \mathrm{~cm}^{-1}$ were induced to oscillate (vibrate, rotate and translate) at $1290 \mathrm{~cm}^{-1}$. All this was conditioned by the increase in the kinetic energy of the oscillation of chemical bonds. A further increase in the wave number over $1305 \mathrm{~cm}^{-1}$ led to the oscillation (or vibration, rotation and translation) of molecular bonds of another organic compound for which the characteristic spectral band was at $1310 \mathrm{~cm}^{-1}$. The kinetic energy of oscillation of molecular bonds of this new compound was superposed with the kinetic energy that had induced the occurrence of the spectral band at $1305 \mathrm{~cm}^{-1}$. The intensity of the spectral band increased. The same, or the similar process was also repeated with spectral bands at 1310, 1355 and $1380 \mathrm{~cm}^{-1}$ until the peak of the spectral band was reached at $1395 \mathrm{~cm}^{-1}$ (see Fig. 2). Thus, the increase in the wave number from $1290 \mathrm{~cm}^{-1}$ to $1305 \mathrm{~cm}^{-1}$ induced the oscillation (or vibration, rotation and translation) of just a part of molecular bonds of the organic compound that might consisted of dozens of atoms (e.g. alkanes $\left.\mathrm{CH}_{3}\left(\mathrm{CH}_{2}\right)_{4} \mathrm{CH}_{3}\right)$. A further increase in the wave number from $1305 \mathrm{~cm}^{-1}$ to $1310 \mathrm{~cm}^{-1}$ induced the oscillation (or vibration, rotation and translation) of another part of molecular bonds

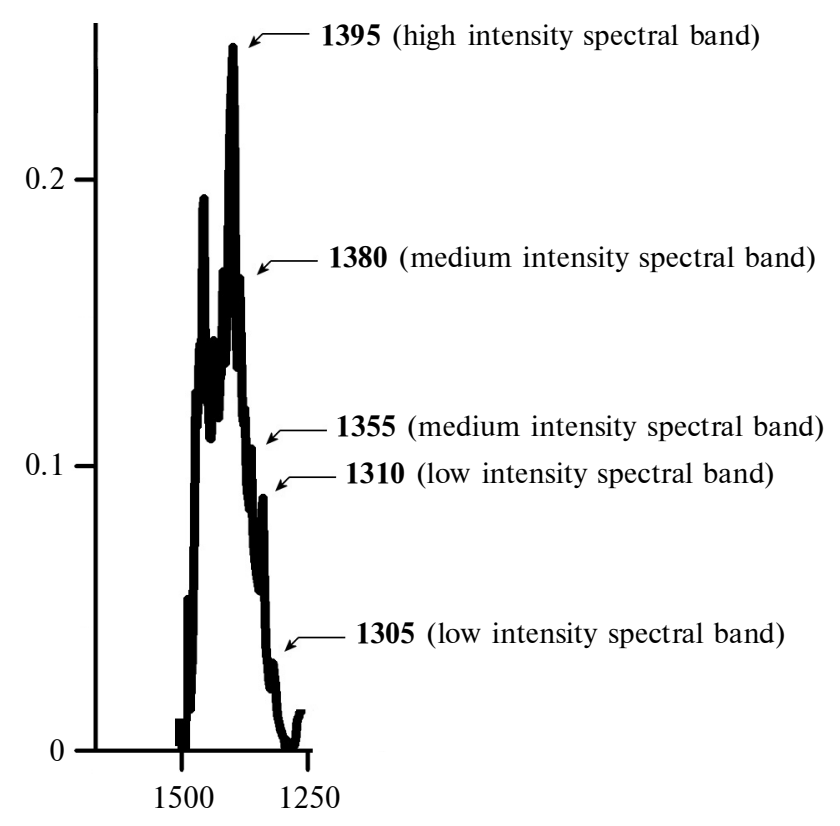

Fig. 2. Empirical model of formation of low intensity spectral bands (illustration of superposition of low intensity spectral bands that partially lose intensity, cancel or increase). Abscissa - wave number, $\mathrm{cm}^{-1}$, ordinate - intensity of absorption of infrared radiation, relative units 
Absorption bands of infrared spectra in leaves of maize inbred lines ZPPL 186, ZPPL 225 and ZP M1-3-3 Sdms

\begin{tabular}{|c|c|}
\hline $\begin{array}{l}\text { Wave number of } \\
\text { spectral band, } \\
\mathrm{cm}^{-1}\end{array}$ & $\begin{array}{l}\text { Assignment of the IR absorption bands to functional groups in organic } \\
\text { molecules }\end{array}$ \\
\hline 3360 & 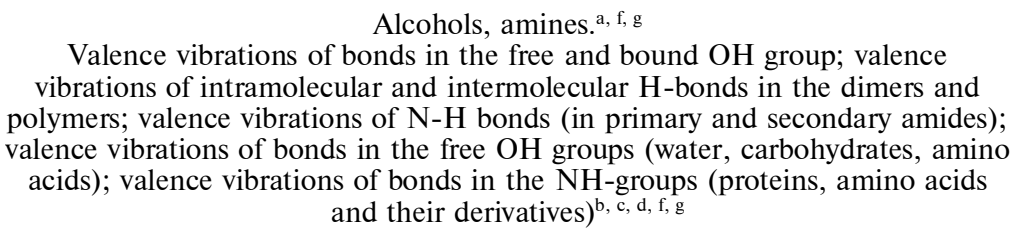 \\
\hline
\end{tabular}

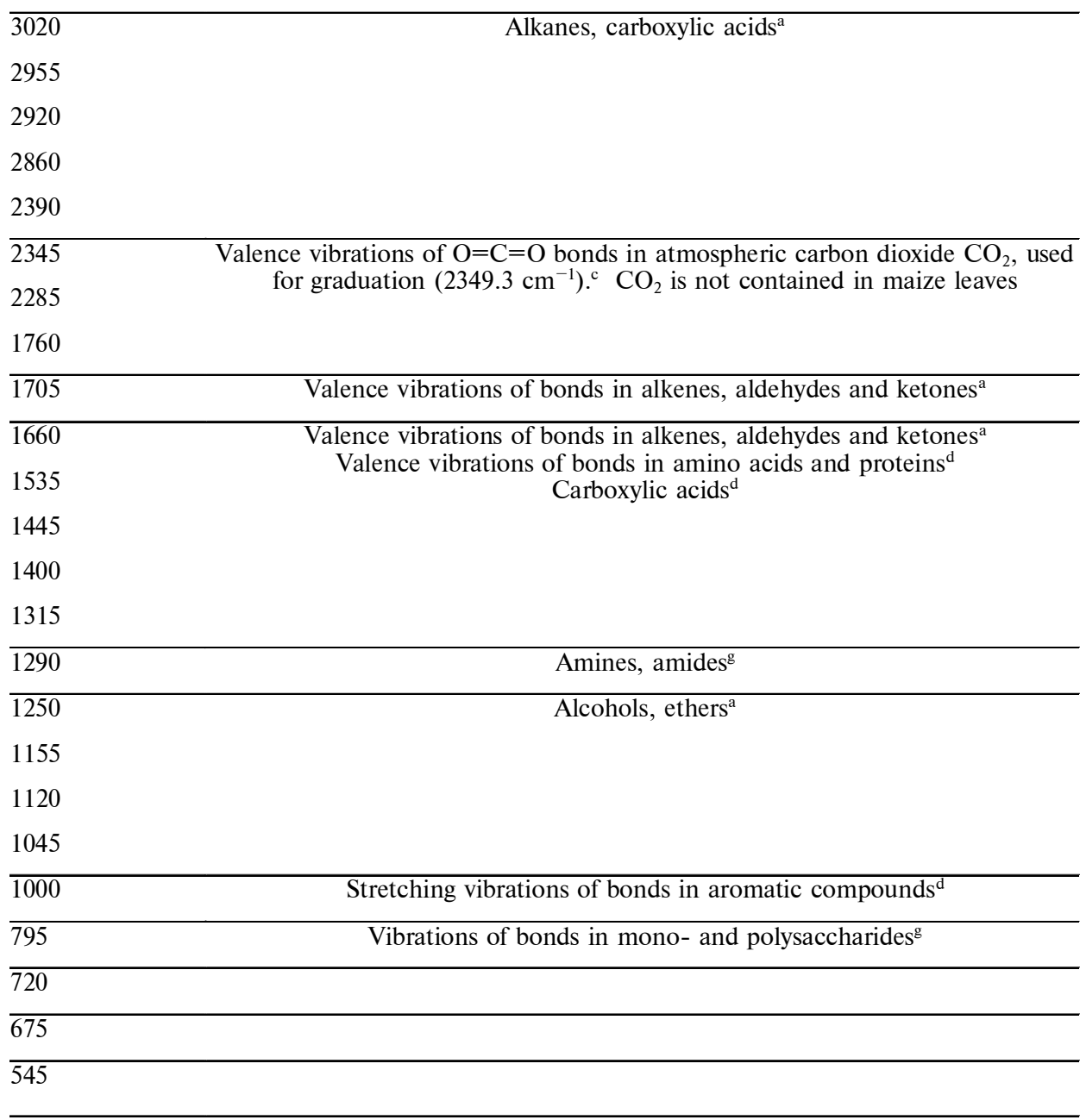

Source: ${ }^{\mathrm{a}}[12],{ }^{\mathrm{b}}[1],{ }^{\mathrm{c}}[2],{ }^{\mathrm{d}}[3],{ }^{\mathrm{e}}[18],{ }^{\mathrm{f}}[21],{ }^{\mathrm{g}}[19]$.

of the organic compound with a large number of atoms. The kinetic energy of these new molecular bonds was superposed with the kinetic energy that induced the appearance of a spectral band at $1290 \mathrm{~cm}^{-1}$. If these energies did not cancel each other and if the interference of similar oscillations of molecular bonds occurred, then the increase in kinetic energy occurred, i.e. the intensity of the spectral band increased. The identical process of increasing the oscillation energy of ever new molecular bonds of the organic compound with a large number of atoms was repeated with the increase 
in the wave number from $1310 \mathrm{~cm}^{-1}$ to $1355 \mathrm{~cm}^{-1}, 1355 \mathrm{~cm}^{-1}$ to $1380 \mathrm{~cm}^{-1}$ and from $1380 \mathrm{~cm}^{-1}$ to $1395 \mathrm{~cm}^{-1}$, i.e. until the maximum amplitude of the spectral band was reached (see Fig. 2).

Noticeably separated spectral bands were registered at the following wave numbers 1034, 1156, 1256, 1320, 1378, 1395, 1513, 1650, 2850, 2958 and $3360 \mathrm{~cm}^{-1}$ in the infrared spectra of the leaves of maize inbred lines (see Fig. $1 a, b, c$ ). These spectral bands corresponded to the oscillations of certain chemical bonds in the molecules of the following compounds: amines, primary and secondary amides, proteins, amino acids, alkanes, alkenes, aldehydes, ketones, aromatic compounds, carbohydrates, carboxylic acids, ethers, alcohols, mono- and polysaccharides.

A spectral band of a high intensity and a significant width at the base was registered in the wavelength range of $3500-3000 \mathrm{~cm}^{-1}$ (see Fig. 1, $a$, $b, c)$. This spectral band may be characteristic of the valence oscillations of the free $\mathrm{OH}$ groups and bound $\mathrm{OH}$ groups; intramolecular and intermolecular $\mathrm{H}$ bonds in dimers and polymers; valence oscillations of $\mathrm{N}-\mathrm{H}$ bonds (primary amides at $3540-3480 \mathrm{~cm}^{-1}, 3420-3380 \mathrm{~cm}^{-1}$, secondary amides at $3460-3420 \mathrm{~cm}^{-1}$ ); and $\mathrm{NH}$ groups (amino acids, amino acid derivatives and proteins).

The similar processes in the biological systems happen in the complex processes of the ion oscillatory transport across the excited membrane [14, 15]. Moreover, today, beyond any doubt, a great attention is paid to the observation of the biological systems. In such contemporary studies, information on genomes and proteomes and their metabolomes, i.e. the concentration of all metabolites and their interactions have been soughed for [13]. This was enabled by the application of the infrared spectroscopy in studying of the structure and properties of organic compounds of leaves of maize inbred lines [10-13].

Based on everything stated above, at least two questions may be posed. First, how to obtain reliable information on the existence of different biogenic organic molecules (substances), whose specificities regarding vibrations cause the appearance of different spectral bands? Second, are there any essential differences in leaves of observed maize inbred lines (ZPPL 186, ZPPL 225, ZP M1-3-3 Sdms) in regard to the existence of different kinetic forms of infrared spectral bands, and thereby of infrared spectra as a whole? If such differences exist, then it can be concluded that there are various organic compounds with different structural properties in leaves of studied maize inbred lines.

The answer to the posed questions can be largely found out in our obtained results. The careful analysis of literature data, i.e. of the intensity, shape, kinetic values, as well as, the range of the wave number of spectral bands [16-19, 22] provides the identification of functional groups of organic compounds (Table). When the same parameters presented in Table and Fig. 1, $a, b, c$ are compared, it can be concluded that structural properties of organic compounds were similar for all three maize inbred lines. However, in case of high intensity spectral bands, such as the spectral band at $3360 \mathrm{~cm}^{-1}$, significant differences in the intensity of spectral bands occurred in observed maize inbred lines. Thus, the intensity of the spectral band in the inbred line ZPPL 186 was higher by approximately $20 \%$ and $10 \%$ than in inbred lines ZPPL 225 and ZP M1-3-3 Sdms, respectively. 
Finally, an attempt was made to present a supplemented methodology in the research of spectral bands of different intensities, shapes and kinetics for the leaves of studied maize inbred lines. Furthermore, the identification of organic molecules was performed and their structure was determined in various spectral bands of maize inbred lines. An attempt to observe and analyse low intensity spectral bands was made, with the intention of explaining their instability and interdependence from the perspective of a different character of valence bonds movements in organic molecules, and their active groups.

Conclusion. Infrared spectroscopy was applied for the first time to register and analyse all spectral bands contained in leaves of high yielding maize inbred lines ZPPL 186, ZPPL 225 and ZP M1-3-3 Sdms. Infrared spectra of leaves of studied maize inbred lines were characterised by up to 30 spectral bands within the range of wave number of $500-3500 \mathrm{~cm}^{-1}$. Spectral bands of leaves of maize inbred lines can be differently pronounced, can be of unequal intensity, different shapes and complex kinetics.

Low intensity spectral bands (up to 26) in the infrared spectrum of leaves of observed maize inbred lines were particularly studied. Besides being of low intensity, they were single or grouped, had different shapes and a complex kinetic structure. Low intensity spectral bands developed in leaves of maize inbred lines provided the identification of organic compounds and their functional groups: amines, amides, proteins, alkanes, alkenes, aldehydes, ketones, aromatic compounds, carboxylic acids, ethers, alcohols, mono- and polysaccharides. On the other hand, high intensity spectral bands provided the identification of organic compounds such as amino acids and their derivatives.

An attempt was made to clarify the nature, role and importance of low intensity spectral bands that indicate an unstable (excited) state of the biological system (leaf) in which various movement modes of molecular bonds occur, and thereby the possibility of the partial cancellation or the enhancement of the intensity of spectral bands.

All presented results and the discussion of numerous parameters of the infrared spectrum of leaves indicate a contribution to the more comprehensive characterisation of properties of observed maize inbred lines.

\section{REFERENCES}

1. Vasiliev, A.V., Grinenko, E.V., Schukin, A.O. \& Fedulina, T.G. (2007). Infrared spectroscopy of organic and natural compounds. St. Petersburg: St. Petersburg. Gos. Forestry technician. Acad. [in Russian].

2. Sverdlov, L.M., Kovner, M.A. \& Kraynov, E.P. (1970). Vibrational spectra of polyatomic molecules. Moscow: Science [in Russian].

3. Tarasevich, B.N. (2012). IR spectra of the main classes of organic compounds. Moscow: Publishing. Moscow State University [in Russian].

4. Krimm, S. \& Bandekar, J. (1986). Vibrational spectroscopy and conformation of peptides, polipeptides and proteins. Advances in Protein Chemistry, 38, pp. 181-364.

5. Ribnikar, S. (1985). Infracrvena i ramanska spektroskopija. In: Fizickohemijske metode. Beograd: Rad.

6. Radenović, Č., Jeremić, M., Maximov, G.V., Filipović, M., Trifunović, B.V. \& Mišović, M.M. (1994). Mogućnost korišćenja ramanske spektroskopije u proucavanju 
otpornosti inbred linija kukuruza prema uslovima stresa. Savremena poljoprivreda, 42, No. 1-2, pp. 5-19.

7. Radenović, Č., Jeremić, M., Maximov, G.V., Mišović, M. M. \& Trifunović, B.V. (1994). Resonance Raman spectra of carotenoids in the maize seed tissue - a new approach in studies on effects of temperatures and other environmental factors on the state of vital functions. J. of Sci. Agricul. Res., 55, No. 4, pp. 33-47.

8. Radenović, Č., Jeremić, M., Maximov, G.V., Mišović, M.N., Selaković, D. \& Trifunović, B.V. (1995). Rezonantni ramanski spektri semena kukuruza i njihova primena u proucavanju životnih funkcija. In Oplemenjivanje, proizvodnja i iskorišćavanje kukuruza - 50 godina Instituta za kukuruz „Zemun Polje” (pp. 291-296), Beograd: Institut za kukuruz „Zemun Polje”.

9. Radenović, Č., Jeremić, M., Maximov, G.V., Mišović, M.N. \& Selaković, D. (1998). Resonance Raman spectra of carotenoides in the maize kernel - a contribution to the evaluation of the kernels resistance to the temperature and the chemical composition of soil. Matica srpska J. Nat. Sci., 95, pp. 41-50.

10. Radenović, Č.N., Maksimov, G.V. \& Grodzinskij, D.M. (2015). Identification of Organic Molecules in Kernels of Maize Inbred Lines Displayed with Infrared Spectra. Fisiol. rast. genet., 47, No. 1, pp. 15-24.

11. Radenović, Č.N., Maksimov, G.V., Tyutyaev, E.V., Syusin, I.V., Shutova, V.V., Secanski, M.D., Srdić, J.Ž., Videnović, Ž.V. \& Popović, A.S. (2015). Structural Properties of Maize Hybrids Established by Infrared Spectra, Matica srpska J. Nat. Sci., No. 129, pp. 3544.

12. Radenovich, C.H., Maksimov, G.V., Tutyaev, E.V., Shutova, V.V., Delich, N., Chamdzhia, Z., Pavlov, J. \& Jovanovic, J. (2016). Identification of organic compounds in corn hybrids (Zea mays L.) of Serbian breeding using infrared spectra. Selskokhozyaystvennaya biologiya, 51, No. 5, pp. 645-653 [in Russian].

13. Radenović, Č.N., Maksimov, G.V., Shutova, V.V., Delić, N.S., Milenković, M.V., Pavlović, M.D. \& Beljanski, M.V. (2018). The study by the methods of infrared spectroscopy of the stretching and twisting vibrations of chemical bonds in functional groups of organic compounds contained in grains of maize inbred lines. Fisiol. rast. genet., Vol. 50, No. 4, pp. 322-330.

14. Kols, O.R., Maksimov, G.V. \& Radenovich, Ch.N. (1993). Biophysics of Rhythmic Excitation. Moscow: Publishing. Moscow State University [in Russian].

15. Radenović, Č. (1998). Transportni procesi kroz membranu. In Savremena biofizika (pp. 1-90), Beograd: Velarta.

16. Vollhardt, P.C. \& Schore, N.E. (1996). Organic Chemistry. New York: W.H. Freeman and Company.

17. White, P.J. \& Johnson, L.A. (2003). Corn: Chemistry and Technology. Minnesota: American Association of Cereal Chemists.

18. Amir, R.M., Anjum, F.M., Khan, M.I., Khan, M.R., Pasha, I. \& Nadeem, M. (2013). Application of Fourier transform infrared (FTIR) spectroscopy for the identification of wheat. J. Food Sci. Technol., 50, pp. 1018-1023.

19. Jackson, M. \& Mantsch, H.H. (2006). Infrared spectroscopy, ex vivo tissue analysis. In Biomedical Spectroscopy. Encyclopedia of Analytical Chemistry (pp. 131-156), John Wiley \& Sons Ltd.

20. Chalmers, J.M. (2002). Mid-infrared spectroscopy: Anomalies, artifacts and common errors in using vibrational spectroscopy techniques. In Handbook of Vibrational Spectroscopy, John Wiley \& Sons Ltd.

21. Yu, P., McKinnon, J.J., Christensen, C.R. \& Christensen, D.A. (2004). Imaging molecular chemistry of Pioneer corn. J. Agric. Food Chem., 52, pp. 7345-7352.

22. Skoog, D.A., Holler, F.J. \& Crouch, S.R. (2007). Principles of instrumental analysis. Belmont: Thomson Higher Education.

Received 23.09.2019 


\section{ДЕТАЛЬНОЕ ИЗУЧЕНИЕ ПАРАМЕТРОВ ИНФРАКРАСНЫХ СПЕКТРОВ ЛИСТЬЕВ - ВКЛАД ВО ВСЕСТОРОННЕЕ ОПРЕДЕЛЕНИЕ СВОЙСТВ ИНБРЕДНЫХ ЛИНИЙ КУКУРУЗЫ}

Ч.Н. Раденович1,2, Г.В. Максимов 3 , В.В. Шутова 4 , О.В. Слатинская ${ }^{3}$, Ф.Ф. Протопопов 3 ,

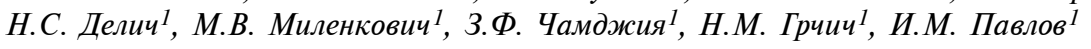

${ }^{1}$ Институт кукурузы «Земун Поле», Белград, Сербия

${ }^{2}$ Факультет физической химии Белградского университета, Белград, Сербия

${ }^{3}$ Биологический факультет Московского государственного университета им. М.В. Ломоносова, Москва, Россия

${ }^{4}$ Национальный исследовательский Мордовский государственный университет имени Н.П. Огарёва, Саранск, Россия

e-mail: radenovic@sbb.rs

Представлены результаты изучения и обсуждение параметров инфракрасного спектра листьев с целью общей характеристики признаков элитных инбредных линий кукурузы ZPPL 186, ZPPL 225, ZP M1-3-3 Sdms. Предложенная гипотеза состояла в том, что многочисленные спектральные полосы листьев инбредных линий кукурузы, встречающиеся в различных кинетических формах (полосы высокой и низкой интенсивности, одиночные или сгруппированные), следует систематически изучать, и должна быть объяснена динамика их формирования, очень часто вызванная различными колебаниями молекулярных связей. В некоторых случаях существует возможность частичного подавления или увеличения интенсивности спектральных полос. Согласно предложенной гипотезе, спектральные полосы низкой интенсивности предполагают нестабильное состояние биологической системы (листа), которое является следствием возбужденного состояния молекул, радикалов, атомов или ионов в тканях, клетках или биомембранах. Подобные перемещения происходят, когда биологические системы ритмично возбуждаются, а также когда происходит сложный транспорт ионов через возбужденную тилакоидную мембрану. Эти полосы чаше всего появляются в диапазоне волновых чисел 500-1600 см-1. Тем не менее они частично встречаются в волновом диапазоне до $3000 \mathrm{~cm}^{-1}$. Эти спектральные полосы различались по инбредным линиям, использованным в данном исследовании. Систематический анализ спектральных полос листьев изучаемых инбредных линий кукурузы (например, полос высокой интенсивности со значительной шириной при $3370 \mathrm{~cm}^{-1}$ ) показал разницу в их встречаемости: наиболее интенсивное проявление было в листьях инбредной линии ZPPL 186, затем в ZP M1-3-3 Sdms, в то время как самая низкая интенсивность была обнаружена в инбредной линии ZPPL 225. Таким комплексным способом можно идентифицировать не только органические соединения и их структуру в листьях инбредных линий кукурузы, но и также выявить возможность индукции их неустойчивых и конформационных состояний.

Ключевые слова: Zea mays L, инбредная линия, лист, инфракрасные спектры, спектральные полосы.

\section{ДЕТАЛЬНЕ ВИВЧЕННЯ ПАРАМЕТРІВ ІНФРАЧЕРВОНИХ СПЕКТРІВ ЛИСТКІВ - ВНЕСОК У ВСЕБІЧНЕ ВИЗНАЧЕННЯ ВЛАСТИВОСТЕЙ ІНБРЕДНИХ ЛІНІЙ КУКУРУДЗИ}

Ч.Н. Раденович 1,2 , Г.В. Максимов ${ }^{3}$, В.В. Шутова 4 , О.В. Слатинська ${ }^{3}$, Ф.Ф. Протопопов 3 , Н.С. Деліч1, М.В. Міленкович', З.Ф. Чамджия' ${ }^{1}$ Н.М. Грчич1, Й.М. Павлов ${ }^{1}$

${ }^{1}$ Інститут кукурудзи «Земун Поле», Белград, Сербія

${ }^{2}$ Факультет фізичної хімії Белградського університету, Белград, Сербія

${ }^{3}$ Біологічний факультет Московського державного університету

ім. М.В. Ломоносова, Москва, Росія 
${ }^{4}$ Національний дослідний Мордовський державний університет ім. Н.П. Огарьова,
Саранськ, Росія
e-mail: radenovic@sbb.rs

Представлено результати вивчення та обговорення параметрів інфрачервоного спектра листків з метою загальної характеристики ознак елітних інбредних ліній кукурудзи ZPPL 186, ZPPL 225, ZP M1-3-3 Sdms. Запропонована гіпотеза полягала в тому, що численні спектральні смуги листків інбредних ліній кукурудзи, які трапляються в різних кінетичних формах (смуги високої та низької інтенсивності, поодинокі або згруповані), слід систематично вивчати, і має бути пояснена динаміка їх формування, дуже часто викликана різними коливаннями молекулярних зв'язків. У деяких випадках існує можливість часткового пригнічення або збільшення інтенсивності спектральних смуг. Згідно із запропонованою гіпотезою, спектральні смуги низької інтенсивності припускають нестабільний стан біологічної системи (листка), який є наслідком збудженого стану молекул, радикалів, атомів або іонів у тканинах, клітинах чи біомембранах. Подібні переміщення відбуваються, коли біологічні системи ритмічно збуджуються, а також коли здійснюється складний транспорт іонів через збуджену тилакоїдну мембрану. Ці смуги найчастіше з'являються в діапазоні хвильових чисел 500-1600 см с $^{-1}$ Втім вони частково трапляються в хвильовому діапазоні до $3000 \mathrm{~cm}^{-1}$. Ці спектральні смуги розрізнялися по інбредних лініях, використаних у цьому дослідженні. Систематичний аналіз спектральних смуг листків досліджуваних інбредних ліній кукурудзи (наприклад, смуг високої інтенсивності зі значною шириною при $3370 \mathrm{~cm}^{-1}$ ) показав різницю в їх зустрічальності: найінтенсивніший прояв був у листках інбредної лінії ZPPL 186, потім в ZP M1-3-3 Sdms, тоді як найнижча інтенсивність була виявлена в інбредної лінії ZPPL 225. Таким комплексним способом можна не тільки ідентифікувати органічні сполуки та їх структуру в листках інбредних ліній кукурудзи, а й виявити можливість індукції їх нестійких і конформаційних станів.

Ключові слова: Zea mays L, інбредна лінія, листок, інфрачервоні спектри, спектральні смуги. 